Check for updates

Cite this: RSC Adv., 2019, 9, 31645

\title{
Adsorption performance of antimony by modified iron powder
}

\begin{abstract}
Chun Zhang, (D) Haiyan Jiang, Yumei Deng and Aihe Wang
Antimony pollution resulting from industrial production is a great threat to the environment, ecology and the human body. Zero-valent iron powder is low-cost and easy to obtain. Nevertheless, the lower adsorption capacity limits its application when it is used as an adsorbent. In the present study, ballmilling and acid modification were developed to change its surface characteristics and $\gamma-\mathrm{Fe}_{2} \mathrm{O}_{3}, \gamma-$ $\mathrm{FeOOH}$ and $\mathrm{Fe}_{3} \mathrm{O}_{4}$ were obtained after treatment, which promoted its adsorption capacity. Compared with the raw iron powder, the adsorption capacities for $\mathrm{Sb}(\mathrm{II})$ and $\mathrm{Sb}(\mathrm{V})$ using the modified material were increased from $12.93 \mathrm{mg} \mathrm{g}^{-1}$ and $5.47 \mathrm{mg} \mathrm{g}^{-1}$ to $17.96 \mathrm{mg} \mathrm{g}^{-1}$ and $10.58 \mathrm{mg} \mathrm{g}^{-1}$, respectively. The study showed that the experimental data fitted the Langmuir model and the pseudo-first-order kinetic model better; the adsorption process was monolayer and chemically controlled at pH $5.0 \pm 0.2$. XPS and FT-IR analysis showed that $\mathrm{Fe}-\mathrm{O}-\mathrm{Sb}$ bonds arose during the adsorption process. The effect of $\mathrm{pH}$ on the adsorption capacity was also studied and the $\mathrm{pH}$ affected the adsorption of $\mathrm{Sb}(\mathrm{v})$ more than the adsorption of $\mathrm{Sb}($ III). In addition, the modified iron powder presented better efficiency when applied to the removal of low levels of antimony in drinking water. Based on the increase of adsorption capacity and low cost, iron powder should be a promising adsorbent for aqueous antimony removal.
\end{abstract}

Received 23rd July 2019

Accepted 13th September 2019

DOI: $10.1039 / \mathrm{c} 9 \mathrm{ra0} 5646 \mathrm{~g}$

rsc.li/rsc-advances containing antimony in the Longxing Antimony Industry Co. Ltd., in Gansu province in China resulted in excessive amounts of antimony in more than $300 \mathrm{~km}$ of the Jialing River and the western Han River. The leakage event involved Gansu, Shanxi and Sichuan provinces and brought great threat to the safety of the drinking water and the ecological system. ${ }^{6,7}$ After diffusion into the ecological environment, it is difficult for antimony to be enriched; the antimony contaminated soil and water resources may cause great harm to the human body through the food chain. Consequently, it is necessary to develop efficient technologies to treat antimony containing wastes to reduce the antimony pollution factor from the emission source.

Antimony has two valence states, trivalent antimony ( $\mathrm{Sb}$ (III)) and pentavalent antimony $(\mathrm{Sb}(\mathrm{v}))$. The $\mathrm{Sb}(\mathrm{III})$ has more toxicity than $\mathrm{Sb}(\mathrm{v})$ and can be oxidized into $\mathrm{Sb}(\mathrm{v})$ in oxidizing atmospheres. The occurrence of the $\mathrm{Sb}(\mathrm{v})$ species is ranked as $\mathrm{SbO}_{2}{ }^{-}$ at $\mathrm{pHs}$ below 2, $\mathrm{H}_{2} \mathrm{SbO}_{4}$ at $\mathrm{pH} 2$ and 2.7, $\mathrm{H}_{2} \mathrm{SbO}_{4}{ }^{-}$and $\mathrm{Sb}(\mathrm{OH})_{6}{ }^{-}$ at $\mathrm{pH} 2.7$ and $10.4^{7}$. Antimony containing wastewater is one of the most important wastes in the process of antimony production. Presently, adsorption, electrochemical methods, biological methods, co-precipitation and coagulation-precipitation are generally used to treat antimony containing waste water. ${ }^{3}$ Considering the cost, its application and the secondary pollution, adsorption has been considered as an attractive method because it has been proved to be efficient, cost-effective and simple to perform compared to other methods. ${ }^{3,8}$ Nevertheless, the core part of the adsorption techniques is the adsorption material, which is the key factor of the treatment.
School of Municipal and Mapping Engineering, Hunan City University, Yiyang 413000, China. E-mail: zhangchun7912@163.com; Fax: +86 737 4628718; Tel: +86 737 4628718 
As reported, iron oxides have strong binding for antimony and multiple iron oxides have been demonstrated to be effective for $\mathrm{Sb}$ removal. Both $\mathrm{Sb}$ (III) and $\mathrm{Sb}$ (v) appear to be adsorbed strongly to iron oxides, and thereby greatly affect the speciation, mobility and the fate in the environment. The iron oxide minerals, including the hydrous ferric oxides: goethite, akageneite, lepidocrocite, and hematite showed favourable affinity for $\mathrm{Sb}$ (III) and $\mathrm{Sb}$ (v). Additionally, some magnetic iron oxides and metal-doped ferrites were synthesized to remove the antimony in wastewater.,10 Previous researchers synthesized validated iron oxy-hydroxide $(\mathrm{FeOOH})$ and amorphous $\mathrm{Fe}_{3} \mathrm{O}_{4} / \mathrm{FeOOH}$ nanocomposite for the removal of $\mathrm{Sb}$ (III) and $\mathrm{Sb}(\mathrm{v})$ from drinking water with an $\mathrm{Sb}$ level below the regulation limit of $5 \mu \mathrm{g} \mathrm{L}^{-11}$. In recent years, the zero-valent iron $\left(\mathrm{Fe}^{0}\right)$ has drawn increasing attention as an effective remediation medium for many contaminants and was considered to be promising and costeffective. Whereas, the zero-valent iron nanoparticles generally present high agglomeration and lack chemical stablity. ${ }^{12,13}$

In this research, the granulated zero-valent iron powders were adopted as a new adsorbent and then they were activated and stabilized using acetic acid. The physicochemical characteristics of the modified and activated iron powders were determined by the particle size, XRD and SEM analyses. Additionally, the characteristics of the antimony adsorption process and the antimony removal mechanisms by the granular adsorbent were determined using a combination of XRD, XPS and FTIR observations and the probable schematic process diagram for the adsorption process was developed.

\section{Materials and methods}

\subsection{Materials}

All the chemical regents used in this study were of analytical grade and were purchased from Sinopharm Chemical Reagent Beijing Co., Ltd., and used without further purification. All the solutions used were prepared using deionized water. The weighed $\mathrm{K}_{2} \mathrm{H}_{2} \mathrm{Sb}_{2} \mathrm{O}_{7} \cdot 4 \mathrm{H}_{2} \mathrm{O}$ was dissolved in $1 \mathrm{~L}$ of deionized water to prepare the $\mathrm{Sb}(\mathrm{v})$-containing solution and $\mathrm{Sb}_{2} \mathrm{O}_{3}$ (III) was dissolved using $2.0 \mathrm{~mol} \mathrm{~L}^{-1} \mathrm{HCl}$. It should be noted that $\mathrm{Sb}$ (III) in all figures in this paper represents uncomplexed-Sb(III) for simplification.

\subsection{Sample preparation and characterization}

The iron powders adopted in the experiments were obtained from the pharmaceutical group, China. The stainless-steel balls were used as the ball grinding medium. After grinding for two hours, the sample was collected and the particle size change was determined. Then, the ground iron powders were immersed in acetic acid solution with a $\mathrm{pH}$ of 5.0 and mixed for 24 hours at a speed of $160 \mathrm{rpm}$. After filtration using a $0.45 \mu \mathrm{m}$ membrane, the immersed iron powders were collected and dried in a vacuum drying oven and characterized, and were then ready for the following batch experiments.

\subsection{Batch adsorption experiments}

2.3.1 Adsorption isotherm. The adsorption isotherms and kinetics for $\mathrm{Sb}(\mathrm{III})$ and $\mathrm{Sb}(\mathrm{v})$ on the activated and modified iron powder granules at $25{ }^{\circ} \mathrm{C}$ were determined using $\mathrm{Sb}(\mathrm{III})$ and $\mathrm{Sb}(\mathrm{v})$ containing solutions with initial concentrations from 0 to $20 \mathrm{mg} \mathrm{L}^{-1}$. The adsorbent dose was $0.5 \mathrm{~g} \mathrm{~L}^{-1}$ at a $\mathrm{pH}$ of $5.0 \pm 0.2$ and the reaction time was $360 \mathrm{~min}$. The $\mathrm{pH}$ of the solution was regulated using $0.01 \mathrm{~mol} \mathrm{~L}^{-1} \mathrm{HCl}$ and $\mathrm{NaOH}$. After the solid-liquid separation, the concentrations in the remaining solution were determined using an ICP method. Then, the experimental data were fitted according to the Langmuir and the Freundlich models and the relative constants were calculated.

2.3.2 Adsorption kinetics. The effect of reaction time on the adsorption of $\mathrm{Sb}(\mathrm{III})$ and $\mathrm{Sb}(\mathrm{v})$ by the materials were measured in a series of $100 \mathrm{~mL}$ polythene centrifuge tubes for 1, 2, 4, 6, 8, 10 and $12 \mathrm{~h}$. The temperature was set at $25 \pm 1{ }^{\circ} \mathrm{C}$, the adsorbent dose used was $0.5 \mathrm{~g} \mathrm{~L}^{-1}$ and the $\mathrm{pH}$ was $5 \pm 0.2$. The initial $\mathrm{Sb}$ concentration was determined to be $20 \mathrm{mg} \mathrm{L}^{-1}$. After the reaction, the mixture was separated and the solution was analyzed to determine residual antimony concentration and the kinetic characteristics using the pseudo-first-order kinetic model and the pseudo-second-order kinetic model.

2.3.3 Effect of $\mathbf{p H}$. The effects of $\mathrm{pH}$ on the adsorption capacity of $\mathrm{Sb}(\mathrm{III})$ and $\mathrm{Sb}(\mathrm{v})$ by the modified material were determined. The reaction temperature was set at $25 \pm 1{ }^{\circ} \mathrm{C}$. The initial $\mathrm{Sb}$ (III) and $\mathrm{Sb}(\mathrm{v})$ concentrations were both determined to be $20 \mathrm{mg} \mathrm{L}^{-1}$. The adsorbent dose was $0.25 \mathrm{~g} \mathrm{~L}^{-1}$ and the experimental $\mathrm{pH}$ range was between 3 and 10. The total reaction time was $360 \mathrm{~min}$. The effect mechanism was also determined.

2.3.4 Application for the removal of low-levels of antimony in a water source. The application prospects of the modified iron powder in the removal of low-levels of antimony in a water source were also studied. The reaction temperature was also set at $25 \pm$ $1{ }^{\circ} \mathrm{C}$ and the adsorbent dose was $0.25 \mathrm{~g} \mathrm{~L}^{-1}$; the $\mathrm{pH}$ of the solution was set at $7.0 \pm 0.2$ and the total solution volume was $100 \mathrm{~mL}$. The total reaction time was $360 \mathrm{~min}$ and all the experiments were completed three times in parallel and the experimental errors were within $5 \%$.

\subsection{Analytical methods}

The residual $\mathrm{Sb}(\mathrm{III})$ or $\mathrm{Sb}(\mathrm{v})$ concentrations in the solutions were determined by ICP-AES (VG PQ ExCell, Thermo Electron Corporation). The $\mathrm{pH}$ of the solutions was measured using a $\mathrm{pH}$ meter (PHS-3B, Jingke, Shanghai, China). The X-ray diffraction patterns of the material were recorded using an X-ray diffractometer (D8 Discover, Bruker) with $\mathrm{Cu} \mathrm{K} \alpha$ radiation $(40 \mathrm{kV}, 40$ $\mathrm{mA}$ ). The SEM, and FT-IR analyses were completed using scanning electron microscopy (Tecnai G2, FEI), and the FourierTransform Infrared Spectrometry (Nicolet iS10, Nicolet), respectively. The X-ray photoelectron spectroscopy (XPS) spectra were obtained with an XPS analyzer (ESCALAB250Xi, ThermoFisher) with an $\mathrm{Al} \mathrm{K} \alpha \mathrm{X}$-ray source (power: $200 \mathrm{~W}$ ).

\section{Results and discussion}

\subsection{Material characterization}

The differential particle size distribution of the raw and the ground iron powders are presented in Fig. 1. The average particle size was reduced from about $-105 \mu \mathrm{m}$ to $-50 \mu \mathrm{m}$ after 


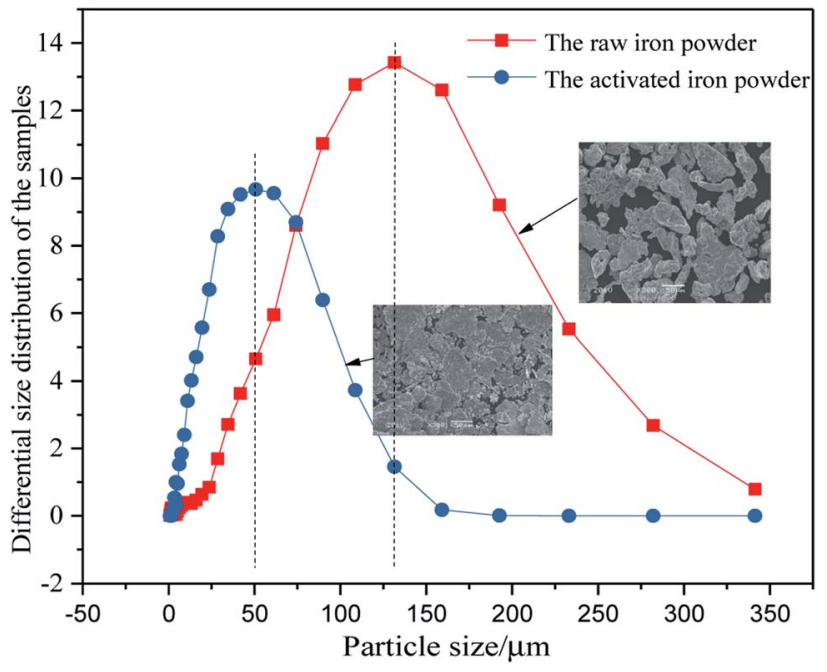

Fig. 1 Changes in the particle size distribution of the raw and the ground iron powders.

the raw iron powders were milled. As Fig. 1 shows, the largest particle size between $108.61 \mu \mathrm{m}$ and $131.47 \mu \mathrm{m}$ was obtained for $13.42 \%$ of the total particles before ball-milling treatment. Accordingly, the largest size between $41.84 \mu \mathrm{m}$ and $50.64 \mu \mathrm{m}$ was obtained for $9.67 \%$ of the total particles after ball-milling treatment. The ground iron powders were immersed in the acetic acid solution with $\mathrm{pH}$ of 5.0 and mixed for 24 hours. The iron powders with a smaller particle size possessed a more active physical chemistry, which led to the faster formation of the corrosion layer. Then, the immersed iron powders were dried in a vacuum drying oven and characterized. The results are presented in Fig. 2. The surface of the activated and modified iron powders became rough, as shown in Fig. 2(b) and (d), when compared with Fig. 2(a), which implied that new phases had been obtained. The ground iron powders are presented in Fig. 2(d) and the corrosive ground iron powders are shown in Fig. 2(e). The X-ray diffraction analysis of the samples in Fig. 2(f) showed that the diffraction peaks of $\mathrm{Fe}_{3} \mathrm{O}_{4}, \gamma-\mathrm{Fe}_{2} \mathrm{O}_{3}$ and $\gamma$ FeOOH appeared, which implied that the physicochemical property of the treated iron powder had changed greatly.

\subsection{Adsorption isotherm}

The relationship between the equilibrium concentration of $\mathrm{Sb}(\mathrm{III})$ and $\mathrm{Sb}(\mathrm{v})$ in the solution and the loading on the adsorbents is presented in Fig. 3(A). The experimental data fitted was based on the Langmuir and the Freundlich models. The linearized forms of the Langmuir and Freundlich equations of $C_{\mathrm{e}} / q_{\mathrm{e}}$ $\sim C_{\mathrm{e}}$ and $\log q_{\mathrm{e}} \sim \log C_{\mathrm{e}}$ are shown in Fig. 3(B) and (C), respectively. The Langmuir isotherm model is described according to the following expression:

$$
q_{\mathrm{e}}=\frac{q_{\mathrm{m}} K_{\mathrm{L}} C_{\mathrm{e}}}{1+K_{\mathrm{L}} C_{\mathrm{e}}}
$$

where $q_{\mathrm{m}}$ is the maximum adsorption capacity $\left(\mathrm{mg} \mathrm{g}^{-1}\right) ; K_{\mathrm{L}}$ is the constant for the Langmuir model $\left(\mathrm{L} \mathrm{mg}^{-1}\right) ; q_{\mathrm{e}}$ is the

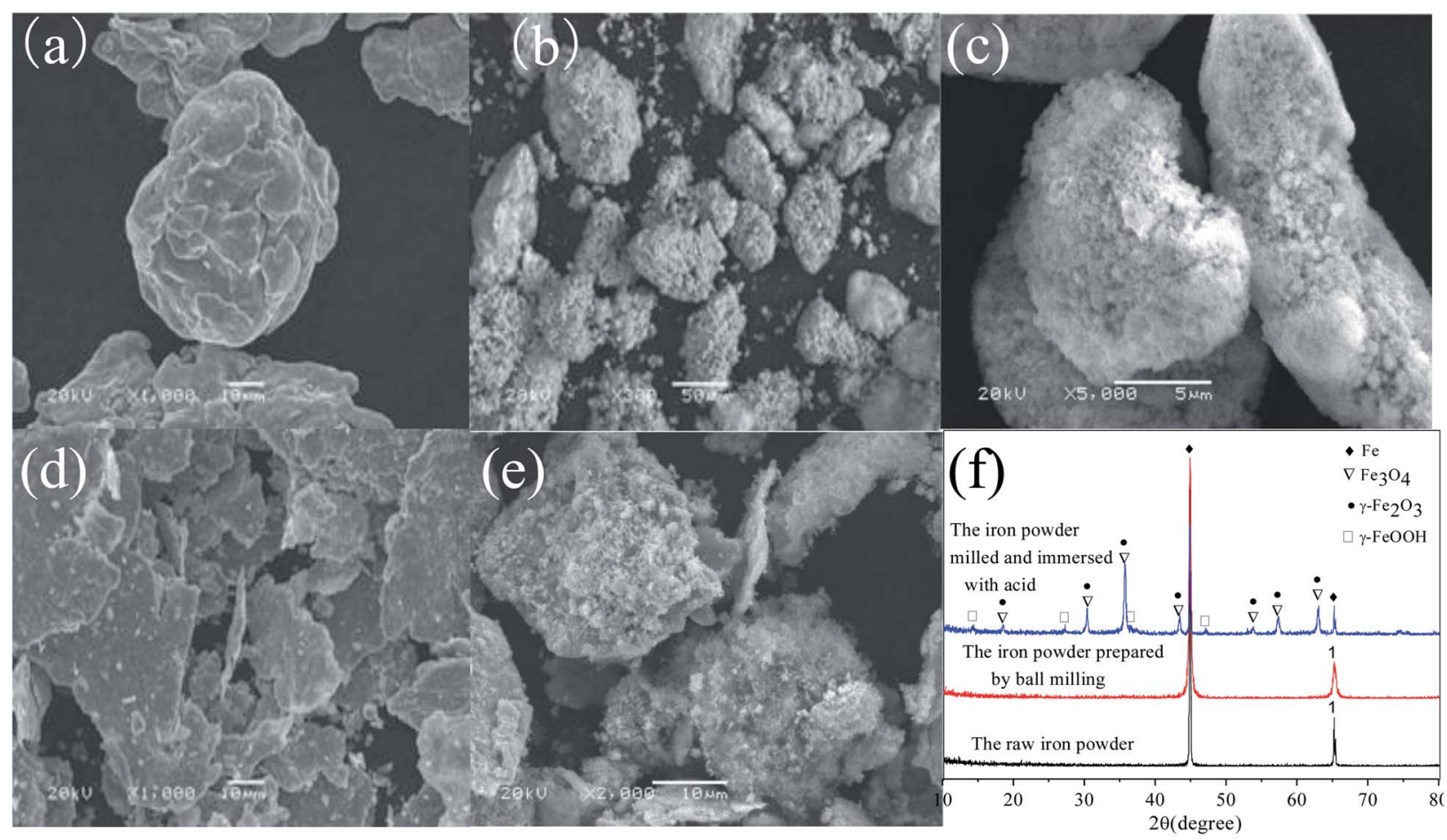

Fig. 2 Changes in the physicochemical properties of the raw and the treated iron powders: (a) the raw iron powders; (b and c) the corrosive iron powders; (d) the ground iron powders; (e) the ground iron powder after corrosion; (f) and the XRD analysis of the ground and corrosive iron powders. 
equilibrium content in the adsorbent $\left(\mathrm{mg} \mathrm{g}^{-1}\right) ; C_{\mathrm{e}}$ is the equilibrium concentration of the adsorbate in the solution $(\mathrm{mg}$ $\left.\mathrm{L}^{-1}\right)$.

The nonlinear Langmuir isotherm expression can be converted into the following linear model:

$$
\frac{C_{\mathrm{e}}}{q_{\mathrm{e}}}=\frac{1}{q_{\mathrm{m}} K_{\mathrm{a}}}+\frac{C_{\mathrm{e}}}{q_{\mathrm{m}}}
$$

The Freundlich isotherm model is an empirical equation used to express adsorption on a heterogeneous surface; the nonlinear and linear expressions are shown in eqn (3) and (4), respectively:

$$
\begin{gathered}
q_{\mathrm{e}}=K_{\mathrm{F}} C_{\mathrm{e}}^{1 / n} \\
\log q_{\mathrm{e}}=\frac{1}{n} \log C_{\mathrm{e}}+\log K_{\mathrm{F}}
\end{gathered}
$$

where $q_{\mathrm{e}}$ and $C_{\mathrm{e}}$ are identical to those in the Langmuir model shown previously; $K_{\mathrm{F}}$ is the Freundlich constant $\left(\mathrm{mg} \mathrm{g}^{-1}\right) ; n$ is a constant implying the adsorption intensity or surface heterogeneity.

The adsorption isotherms for $\mathrm{Sb}(\mathrm{III})$ and $\mathrm{Sb}(\mathrm{v})$ and the fitting results are presented in Fig. 3. The related parameters of the adsorption process and maximum adsorption capacity were estimated according to the fitted linear equations of the Langmuir and Freundlich model and are presented in the Table 1. Just as the Table 1 showed, the correlation coefficients for the Langmuir model $\left(0.9871<R^{2}<0.9978\right)$ were higher than the correlation coefficients for the Freundlich model $\left(0.9184<R^{2}<\right.$ $0.9873)$. The correlation coefficients for all the adsorption cases revealed that the Langmuir model fitted the adsorption of $\mathrm{Sb}$ (III) and $\mathrm{Sb}(\mathrm{v})$ better than the Freundlich model based on the higher correlation coefficients. The Langmuir model is based on the theory of monolayer adsorption on a uniform surface and the adsorption ability of the adsorption sites is uniform. ${ }^{2,14}$

The uptake of the adsorbate only happens on the surface of the adsorbent. The maximum adsorption capacities of the modified iron powders for $\mathrm{Sb}(\mathrm{III})$ and $\mathrm{Sb}(\mathrm{v})$ were $17.96 \mathrm{mg} \mathrm{g}^{-1}$ and $10.58 \mathrm{mg}$ $\mathrm{g}^{-1}$, respectively, which was greatly elevated compared with adsorption of the raw iron powders. However, the adsorption capacities for $\mathrm{Sb}(\mathrm{III})$ and $\mathrm{Sb}(\mathrm{v})$ were still below the values reported in the previous reports., ${ }^{2,14}$ The lower maximum adsorption capacity was because the iron oxides just occurred on the surface of the iron powders, but the completely synthesized iron oxides were adopted in the study. The value of $K_{\mathrm{a}}$ of the modified iron powders for $\mathrm{Sb}$ (III) was higher than that for $\mathrm{Sb}(\mathrm{v})$, which implied that there was a larger
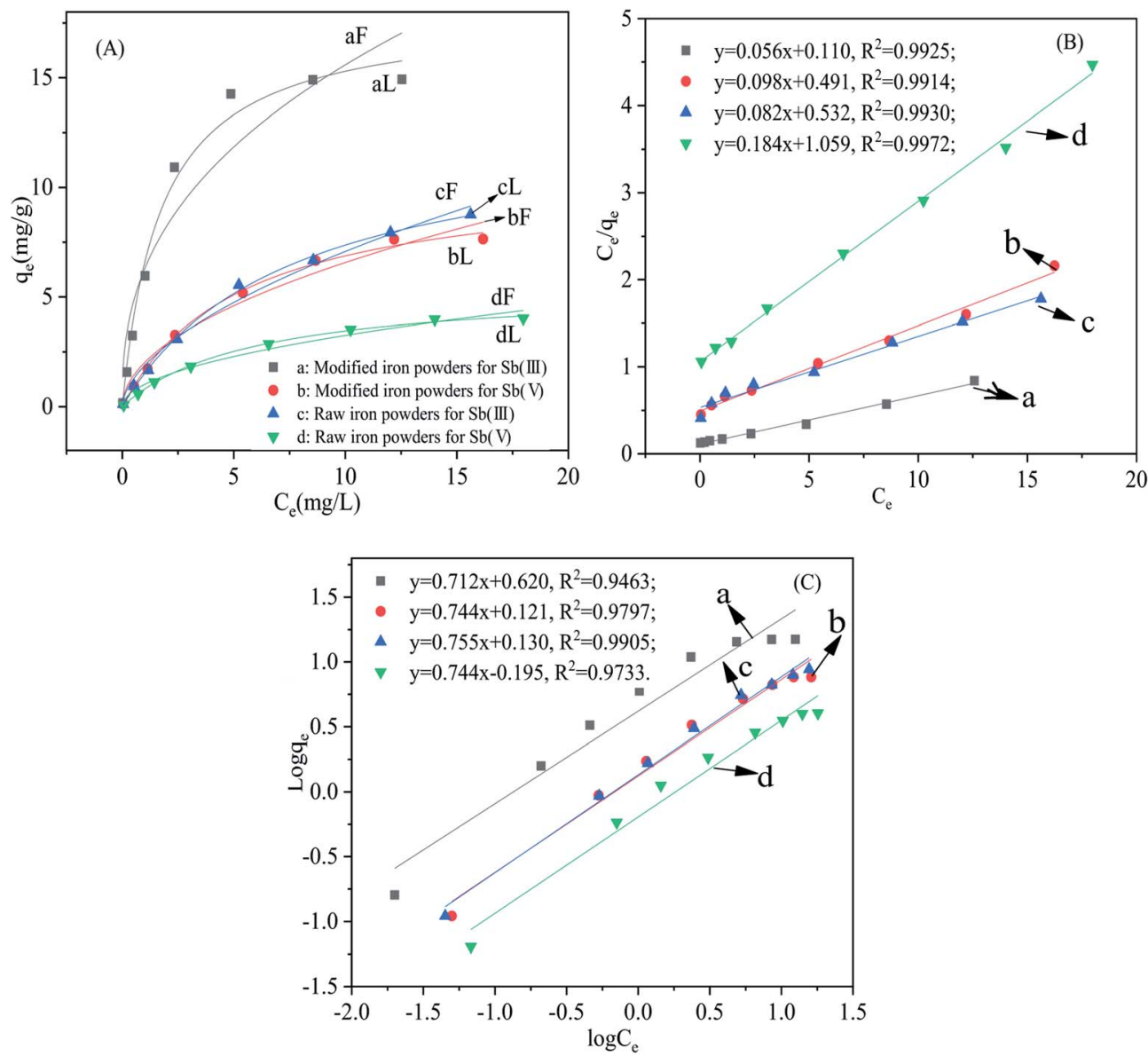

Fig. 3 Adsorption isotherms for $\mathrm{Sb}(\mathrm{II})$ and $\mathrm{Sb}(\mathrm{V})$ : (A) the Langmuir and Freundlich fitting analysis; (B) the linear Langmuir $C_{\mathrm{e}} / q_{\mathrm{e}} \sim \mathrm{C}_{\mathrm{e}}$ analysis; and (C) The linear Freundlich $\log q_{\mathrm{e}} \sim \log C_{\mathrm{e}}$ analysis ( $t=25 \pm 1{ }^{\circ} \mathrm{C}$; adsorbent dose: $0.5 \mathrm{~g} \mathrm{~L}^{-1} ; \mathrm{pH}=5 \pm 0.2$; reaction time: 360 min). 
Table 1 Parameters of the Langmuir and Freundlich models for the adsorption of Sb(III) and Sb(v)

\begin{tabular}{|c|c|c|c|c|c|c|c|}
\hline \multirow[b]{2}{*}{ Material type } & \multirow{2}{*}{$\frac{\text { Equation }}{\text { Parameter }}$} & \multicolumn{3}{|c|}{ Langmuir $\left(q_{\mathrm{e}}=\frac{q_{\mathrm{m}} K_{\mathrm{L}} C_{\mathrm{e}}}{1+K_{\mathrm{L}} C_{\mathrm{e}}}\right)$} & \multicolumn{3}{|c|}{ Freundlich $\left(q_{\mathrm{e}}=K_{\mathrm{F}} C_{\mathrm{e}}{ }^{1 / n}\right)$} \\
\hline & & $q_{\mathrm{m}}\left(\mathrm{mg} \mathrm{g}^{-1}\right)$ & $K_{\mathrm{L}}\left(\mathrm{L} \mathrm{mg}^{-1}\right)$ & $R^{2}$ & $K_{\mathrm{F}}\left(\mathrm{mg} \mathrm{g}^{-1}\right)$ & $n$ & $R^{2}$ \\
\hline The modified iron powders & $\mathrm{Sb}$ (III) & 17.96 & 0.57 & 0.9871 & 6.27 & 2.53 & 0.9184 \\
\hline The modified iron powders & $\mathrm{Sb}(\mathrm{v})$ & 10.58 & 0.18 & 0.9960 & 2.01 & 1.92 & 0.9731 \\
\hline The raw iron powders & $\mathrm{Sb}($ III) & 12.93 & 0.13 & 0.9981 & 1.87 & 1.73 & 0.9873 \\
\hline
\end{tabular}
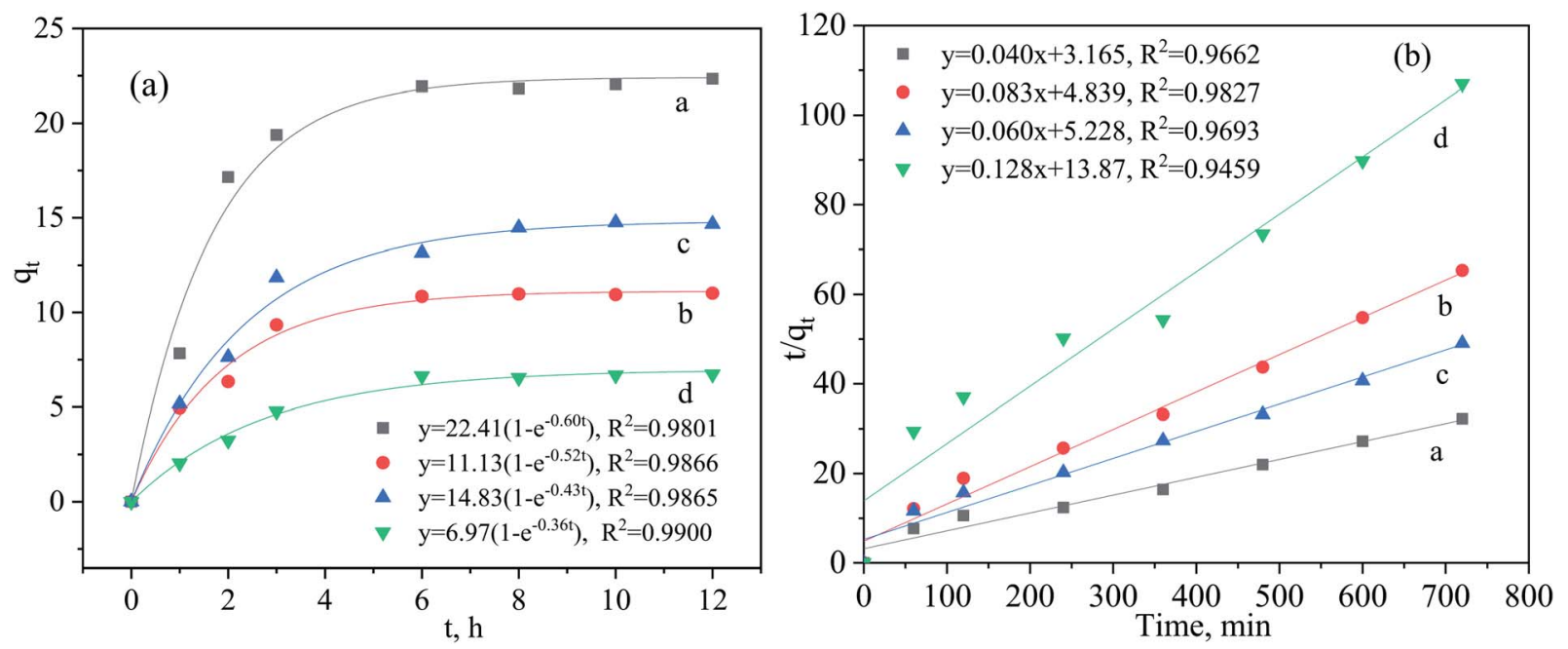

Fig. 4 Adsorption kinetics of $\mathrm{Sb}(\mathrm{III})$ and $\mathrm{Sb}(\mathrm{v})$ : (a) the non-linear pseudo-first-order kinetic model analysis; and (b) the linear pseudo-secondorder kinetic model analysis ( $t=25 \pm 1^{\circ} \mathrm{C}$; adsorbent dose: $0.5 \mathrm{~g} \mathrm{~L}^{-1} ; \mathrm{pH}=5 \pm 0.2$; initial Sb concentration: $20 \mathrm{mg} \mathrm{L} \mathrm{L}^{-1}$; time range: $0-720 \mathrm{~min}$ ).

affinity for $\mathrm{Sb}(\mathrm{III})$ than $\mathrm{Sb}(\mathrm{v})$ on the adsorbent. Although the correlation coefficient for the Freundlich model was smaller than that of the Langmuir model, the value of $K_{\mathrm{F}}$ for the adsorption process using the modified iron powders was higher than that of the raw material, which showed a higher adsorption and bonding affinity. ${ }^{14,15}$

\subsection{Adsorption kinetics}

Based on the previous experiments, it was clear that the adsorption capacity of the modified iron powders increased dramatically compared with the raw iron powders. Moreover, the adsorption kinetics were always used to assess the adsorption efficiency of $\mathrm{Sb}$ (III) and $\mathrm{Sb}(\mathrm{v})$ by the raw and the modified iron powders. In this study, the pseudo-first-order kinetic model, the pseudo-second-order kinetic model and the intraparticle diffusion were used to complete the relative calculation..$^{2,16}$

The non-linear pseudo-first-order kinetic model is expressed as follows:

$$
q_{\mathrm{t}}=q_{\mathrm{e}}\left(1-\mathrm{e}^{k_{1} t}\right)
$$

The above non-linear expression can be converted into the following linear form:

$$
\log \left(q_{\mathrm{e}}-q_{\mathrm{t}}\right)=\log q_{\mathrm{e}}-\frac{k}{2.303} t
$$

\begin{tabular}{|c|c|c|c|c|c|c|}
\hline Material type & $k_{1}\left(\mathrm{~h}^{-1}\right)$ & $q_{\mathrm{e}}\left(\mathrm{mg} \mathrm{g}^{-1}\right)$ & $R^{2}$ & $k_{2}(\mathrm{~g} \mathrm{mg} \mathrm{min}-1)$ & $q_{\mathrm{e}}\left(\mathrm{mg} \mathrm{g}^{-1}\right)$ & $R^{2}$ \\
\hline Modified iron powders for $\mathrm{Sb}(\mathrm{v})$ & 0.52 & 11.13 & 0.9866 & $1.42 \times 10^{-3}$ & 12.05 & 0.9827 \\
\hline Raw iron powders for $\mathrm{Sb}(\mathrm{III})$ & 0.43 & 14.83 & 0.9865 & $0.69 \times 10^{-3}$ & 16.67 & 0.9693 \\
\hline Raw iron powders for $\mathrm{Sb}(\mathrm{v})$ & 0.36 & 6.97 & 0.9900 & $1.18 \times 10^{-3}$ & 7.81 & 0.9459 \\
\hline
\end{tabular}

Table 2 Adsorption kinetics constants for the adsorption of $\mathrm{Sb}$ (III) and $\mathrm{Sb}(\mathrm{V})$ 


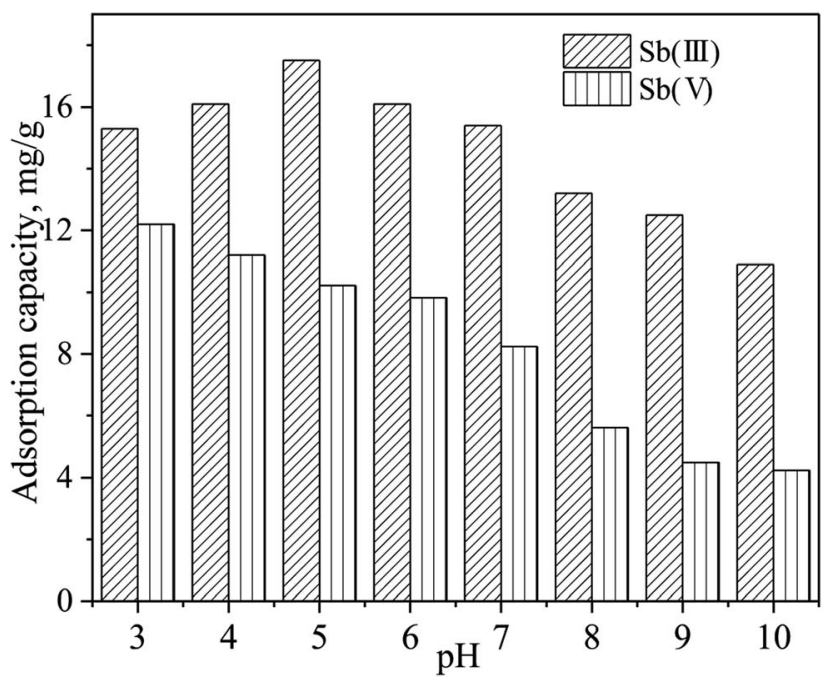

Fig. 5 Effect of $\mathrm{pH}$ on the adsorption capacities for $\mathrm{Sb}(\mathrm{III})$ and $\mathrm{Sb}(\mathrm{V})$ of the modified iron powders $\left(t=25 \pm 1{ }^{\circ} \mathrm{C}\right.$; initial Sb(III) and $\mathrm{Sb}(\mathrm{V})$ concentration: $20 \mathrm{mg} \mathrm{L}^{-1}$; total solution volume: $250 \mathrm{~mL}$; adsorbent dose: $0.25 \mathrm{~g} \mathrm{~L}^{-1}$; $\mathrm{pH}$ range: 3-10; reaction time: $360 \mathrm{~min}$ ).

The pseudo-second-order kinetic model is expressed as follows:

$$
q_{\mathrm{t}}=\frac{q_{\mathrm{e}}{ }^{2} k_{2} t}{1+q_{\mathrm{e}} k_{2} t}
$$

The corresponding linear form is as follows:

$$
\frac{t}{q_{\mathrm{t}}}=\frac{1}{k_{2} q_{\mathrm{e}}^{2}}+\frac{1}{q_{\mathrm{e}}} t
$$

where $q_{\mathrm{t}}\left(\mathrm{mg} \mathrm{g}^{-1}\right)$ is the adsorption capacity at time $t(\mathrm{~min}) ; q_{\mathrm{e}}$ $\left(\mathrm{mg} \mathrm{\textrm {g } ^ { - 1 }}\right)$ is the adsorption amount at equilibrium; $k_{1}\left(\mathrm{~min}^{-1}\right)$

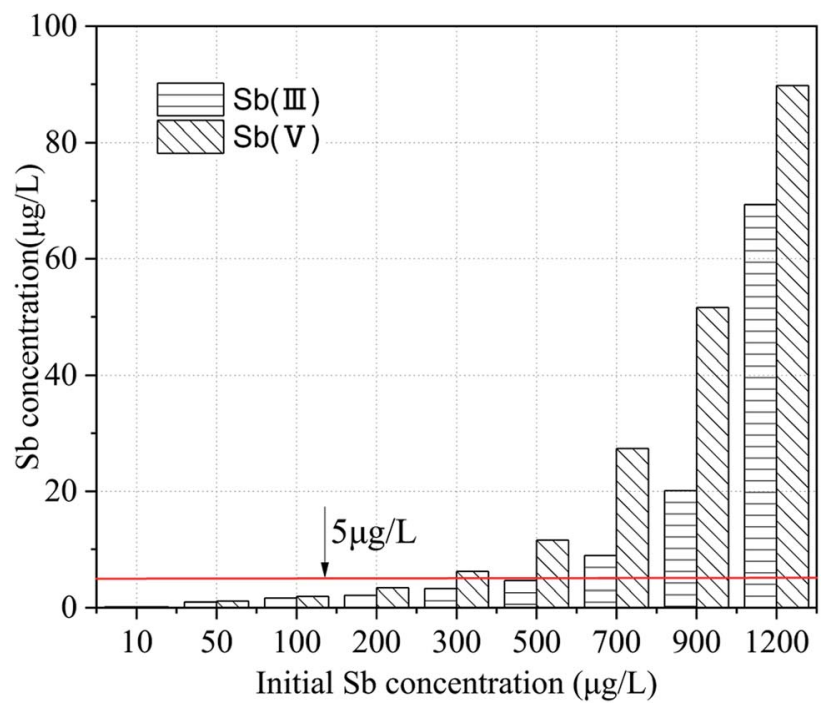

Fig. 6 The remaining antimony concentration after the modified iron powders were used as an adsorbent for low-level antimony removal ( $t$ $=25 \pm 1{ }^{\circ} \mathrm{C}$, adsorbent dose: $0.25 \mathrm{~g} \mathrm{~L}^{-1}, \mathrm{pH}=5.0 \pm 0.2$; total solution volume: $100 \mathrm{~mL}$; reaction time: $360 \mathrm{~min}$ ). and $k_{2}\left(\mathrm{~g} \mathrm{mg}^{-1} \mathrm{~min}^{-1}\right)$ are the equilibrium constants for the pseudo-first and pseudo-second order reactions, respectively.

The effect of the reaction time on the adsorption capacity $\left(q_{\mathrm{t}}\right)$ of $\mathrm{Sb}$ (III) and $\mathrm{Sb}(\mathrm{v})$ at time $t$ by the modified and the raw iron powders are presented in Fig. 4. The non-linear pseudo-firstorder kinetic model and the linear pseudo-second-order kinetic model were adopted to fit the adsorption data.,9 According to the results shown in Fig. 4(a), the uptake of Sb on the adsorbents increased greatly in the first two hours, which was always attributed to the adsorption by the high affinity sites or the precipitation of adsorbate on the surface of the adsorbent. About $85 \%$ uptake of $\mathrm{Sb}$ (III) on the adsorbent occurred in the first three hours and in the following stage, intraparticle diffusion may dominate the adsorption process and the adsorption reached equilibrium after reaction for $6 \mathrm{~h}$. As shown in Table 2, the calculated $q_{\mathrm{e}}$, resulting from the pseudo-firstorder kinetic model, was approximately equal to that from the Langmuir isotherm model and the reaction process was monolayer adsorption and was controlled by the chemical reaction, which was also demonstrated by the results of the XPS and FT-IR analyses. Although the maximum adsorption capacities of the modified iron powders for $\mathrm{Sb}(\mathrm{III})$ and $\mathrm{Sb}(\mathrm{v})$ obtained in this study were relatively lower than those for the pure $\alpha$ $\mathrm{FeOOH}, \alpha-\mathrm{Fe}_{2} \mathrm{O}_{3}$ and metal doped $\mathrm{Fe}_{3} \mathrm{O}_{4},{ }^{9,14}$ the adsorbent (the modified iron powders) in present study can be easily obtained and the method is financially feasible, which could be the greatest advantage of using this material.

\subsection{Effect of $\mathrm{pH}$ on the adsorption process}

The effects of the initial solution $\mathrm{pH}$ (from 3 to 10) on the removal of $\mathrm{Sb}(\mathrm{III})$ and $\mathrm{Sb}(\mathrm{v})$ by the modified iron powders were determined and the results are presented in Fig. 5. According to the results in Fig. 5, the adsorption capacity was reduced from $15.3 \mathrm{mg} \mathrm{g}^{-1}$ to $10.9 \mathrm{mg} \mathrm{g}^{-1}$ for $\mathrm{Sb}$ (III) and from $12.2 \mathrm{mg} \mathrm{g}^{-1}$ to $4.24 \mathrm{mg} \mathrm{g}^{-1}$ for $\mathrm{Sb}(\mathrm{v})$. The initial solution $\mathrm{pH}$ affected the removal of $\mathrm{Sb}$ (III) slightly. However, the adsorption capacity of $\mathrm{Sb}(\mathrm{v})$ decreased greatly with the increase of $\mathrm{pH}$ from 3 to 10 . Results in previous reports showed that the adsorption process of $\mathrm{Sb}$ (III) by hydroxyapatite (at pHs between 5 and 10) and by goethite (at pHs between 2 and 12) was not greatly influenced by the initial solution $\mathrm{pH}^{\mathbf{1 3 , 1 7}}$ The adsorption behavior can also be explained by the values of the points of zero charge. As previously reported, the zero charge of $\gamma-\mathrm{Fe}_{2} \mathrm{O}_{3}, \gamma$-FeOOH and $\mathrm{Fe}_{3} \mathrm{O}_{4}$ were 8.6, 7.3 and 4.5, respectively. ${ }^{2,16}$ Below the value of the zero charge, the surface of the iron oxides can be protonated according to the reaction: $\equiv \mathrm{FeOH}+\mathrm{H}^{+} \leftrightarrow \equiv \mathrm{Fe}-\mathrm{OH}_{2}{ }^{+}$; the protonated form can also promote electrostatic adsorption of $\mathrm{Sb}$ anionic species $\left(\mathrm{H}_{2} \mathrm{SbO}_{3}{ }^{-}, \mathrm{Sb}(\mathrm{OH})_{4}{ }^{-}, \mathrm{H}_{2} \mathrm{SbO}_{4}{ }^{-}, \mathrm{Sb}(\mathrm{OH})_{6}{ }^{-}\right){ }^{10}$ However, above the value of the zero charge, the surface of the iron oxides on the corrosion layer could be coated with negative groups, which decreased the adsorption by the repulsive electrostatic forces according to the reaction: $\equiv \mathrm{FeOH} \leftrightarrow \equiv \mathrm{Fe}_{-} \mathrm{O}^{-}+$ $\mathrm{H}^{+}$; such adsorption behavior was also detected by previous researchers. ${ }^{10,18}$ The $\mathrm{Sb}(\mathrm{III})$ mainly exists as $\mathrm{H}_{3} \mathrm{SbO}_{3}$ and $\mathrm{Sb}(\mathrm{OH})_{3}$ at $\mathrm{pHs}$ between 2.0 and 10.4 and as $\mathrm{H}_{2} \mathrm{SbO}_{3}{ }^{-}$and $\mathrm{Sb}(\mathrm{OH})_{4}{ }^{-}$at pHs above 10.4. Meanwhile, $\mathrm{Sb}(\mathrm{v})$ mainly exists as $\mathrm{H}_{2} \mathrm{SbO}_{4}{ }^{-}$and 

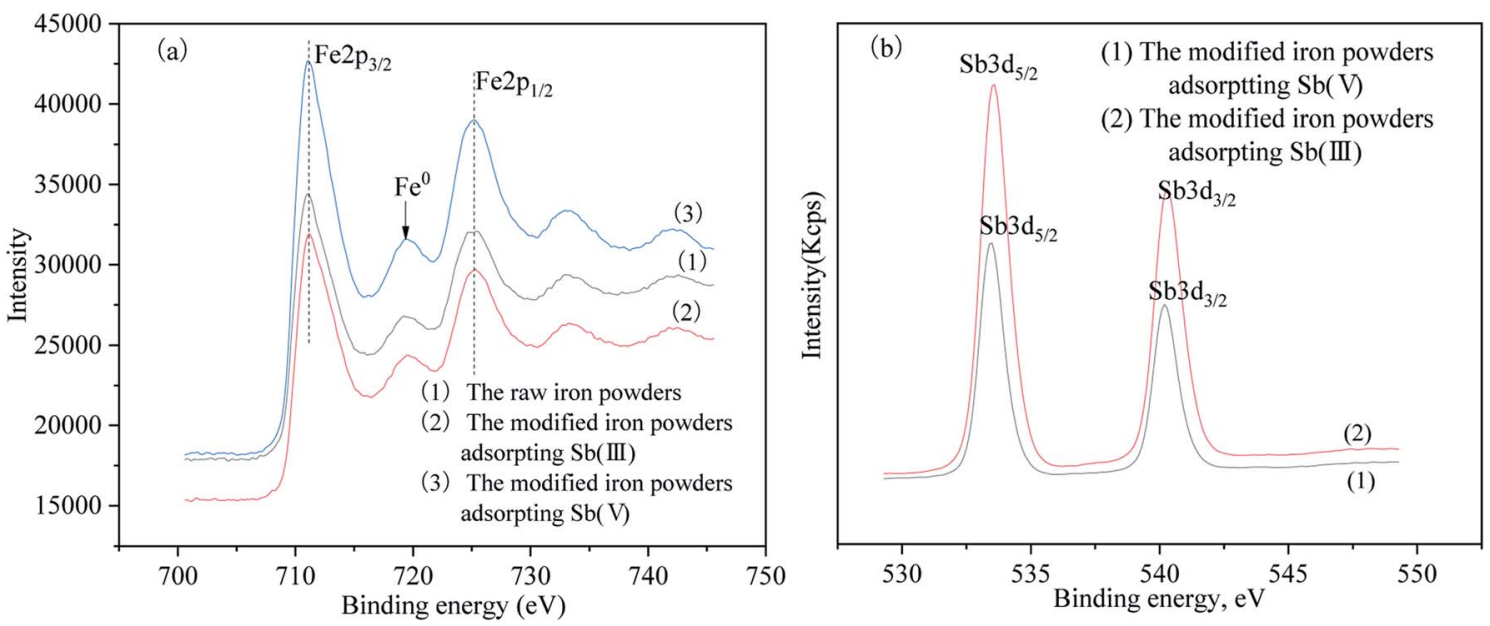

Fig. 7 The XPS spectral analysis of (a) Fe $2 p$ and (b) Sb $3 d$.

Table 3 The peak table data of the XPS analysis

\begin{tabular}{lcccccccc}
\hline Name & Start BE & Peak BE & End BE & Height (CPS) & FWHM (eV) & Area (P) (CPS.eV) & Area (N) & Atomic\% \\
\hline Fe 2p & 738.29 & 711.09 & 706.19 & 22046.07 & 3.73 & 188577.8 & 0.34 \\
Fe 2p & 737.89 & 711.16 & 706.39 & 14555.14 & 3.58 & 111154.1 & 23.28 \\
Fe 2p & 737.39 & 711.03 & 705.89 & 14493.87 & 3.44 & 100607.4 & 0.20 & 0.18 \\
Sb 3d & 550.01 & 540.19 & 537.71 & 47719.02 & 1.26 & 115451.3 & 13.29 \\
Sb 3d & 549.61 & 540.08 & 537.71 & 28863.87 & 1.12 & 63074.44 & 0.10 & 0.05
\end{tabular}

$\mathrm{Sb}(\mathrm{OH})_{6}{ }^{-}$when the $\mathrm{pH}$ is above $2.7^{7}$ The more negatively charged surfaces increased the repulsive forces and inhibited the adsorption of the anionic $\mathrm{H}_{2} \mathrm{SbO}_{3}{ }^{-}$and $\mathrm{Sb}(\mathrm{OH})_{4}{ }^{-}$. The decreased adsorption capacity might be attributed to the electrostatic repulsion.

\subsection{Application of the modified for adsorption of low-level antimony}

The Zijiang river basin lies in the Hunan province, China and provides drinking water to the people in the cities along the river basin. The Lengshuijiang city called 'the Antimony City of the world' is just located in the upper reaches of the Zijiang river and produces more than $30 \%$ of the total antimony production in the world. The concentration of antimony in the river water was between 11 and $14 \mu \mathrm{g} \mathrm{L}^{-1}$ on sunny days and was always more than 10 times the concentration on rainy days, which resulted from the rain washing the antimony down the river. The concentration of antimony during the monitoring period exceeded the concentration $5 \mu \mathrm{g} \mathrm{\textrm {L } ^ { - 1 }}$ specified in the specification of the "Standards for drinking water quality" (GB57492015) of China. The application of the modified iron powders was used for the advanced treatment to remove the antimony from the drinking water. A simulated raw water with different initial antimony concentrations was prepared and the atomic fluorescence spectrometry mothed was adopted to determine the low-level antimony concentration. The treatment results are presented in Fig. 6 . The modified iron powders can reduce the antimony concentration to below $5 \mu \mathrm{g} \mathrm{\textrm {L } ^ { - 1 }}$ when the $\mathrm{Sb}$ (III) and $\mathrm{Sb}(\mathrm{v})$ was no more than $500 \mu \mathrm{g} \mathrm{L}^{-1}$ and $300 \mu \mathrm{g} \mathrm{L}^{-1}$, respectively, which implied that the modified iron powders can be used for the treatment of drinking water with a low-level antimony content. Previous researchers used iron-based oxy-hydroxides as adsorbents to treat groundwater containing $\mathrm{Sb}$ to meet the requirements of the drinking water regulations. The higher efficiency of the validated $\mathrm{FeOOH}$ was confirmed by rapid smallscale column tests, because an adsorption capacity of $3 \mathrm{mg}$

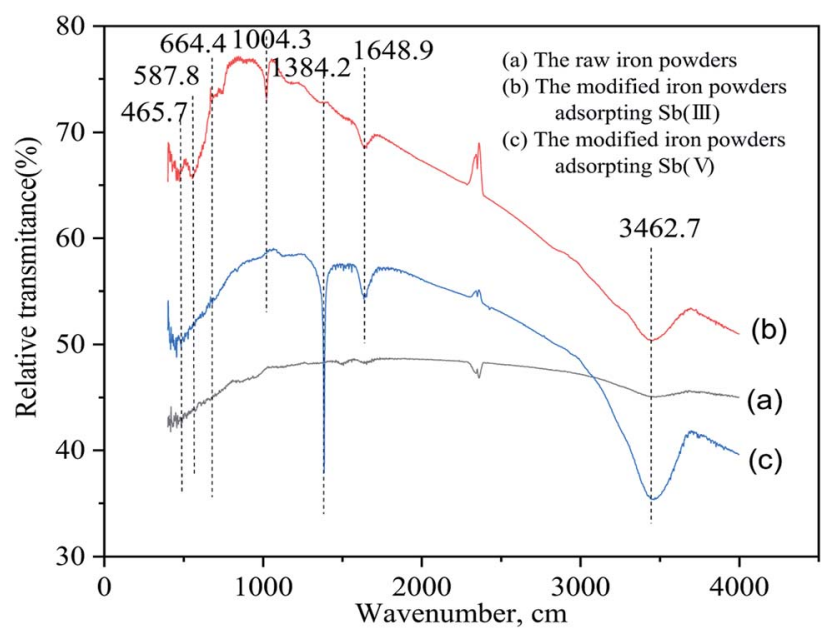

Fig. 8 The FT-IR spectral analysis of the different materials. 


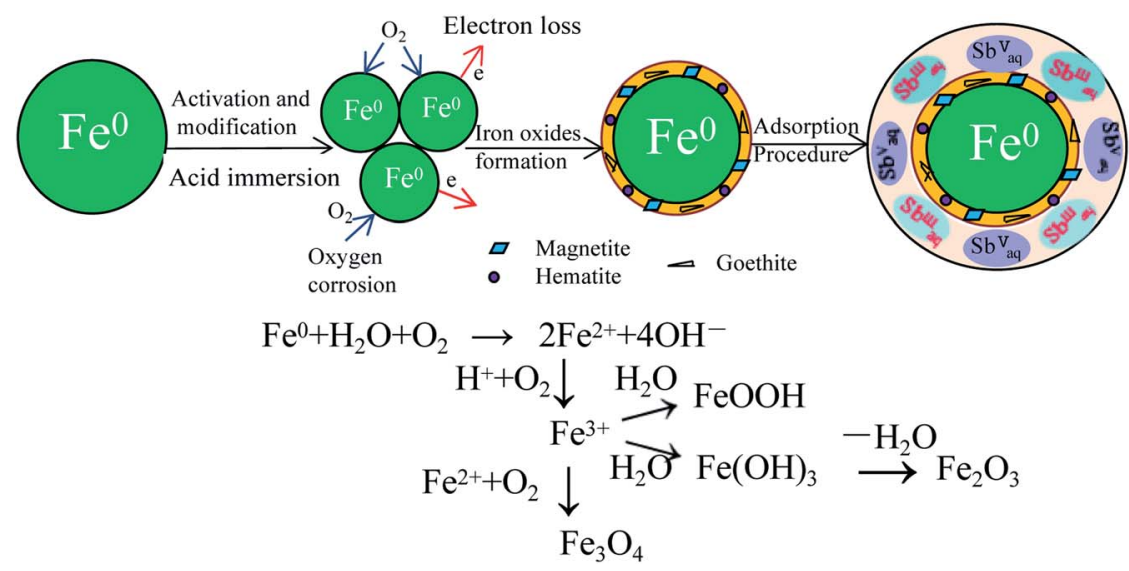

Fig. 9 A probable schematic process diagram for the adsorption process.

$\mathrm{Sb}$ (III) $\mathrm{g}^{-1}$ was determined at a breakthrough concentration of 5 $\mu \mathrm{g} \mathrm{L}{ }^{-1}$. However, it completely failed to achieve $\mathrm{Sb}(\mathrm{v})$ concentrations below $5 \mu \mathrm{g} \mathrm{L^{-1 }}$ even at the beginning of the column experiments. ${ }^{11}$ In view of this, the researchers developed a new amorphous $\mathrm{Fe}_{3} \mathrm{O}_{4} / \mathrm{FeOOH}$ nanocomposite to treat drinking water containing $\mathrm{Sb}(\mathrm{v})$. The addition of the reducing agent such as $\mathrm{Fe}_{3} \mathrm{O}_{4}$ results in the improvement of the $\mathrm{Sb}(\mathrm{v})$ uptake capacity and the intermediate reduction of $\mathrm{Sb}(\mathrm{v})$ to $\mathrm{Sb}$ (III) followed by $\mathrm{Sb}$ (III) adsorption onto the $\mathrm{FeOOH}$ is the possible mechanism which explains the experimental findings. ${ }^{19}$ Compared with the synthesized iron oxide based adsorbents, the preparation of the adsorptive material in the present study has a cost advantage.

\subsection{Adsorption mechanism}

3.6.1 XPS analysis. The $\mathrm{Fe} 2 \mathrm{p}$ and $\mathrm{Sb} 3 \mathrm{~d}$ transmittance spectra of the raw iron powder, the activated and modified iron powders after $\mathrm{Sb}(\mathrm{III})$ or $\mathrm{Sb}(\mathrm{v})$ adsorption at $\mathrm{pH} 5.0 \pm 0.2$ are presented in Fig. 7(a) and (b). According to the results in Fig. 7(a), $\mathrm{Fe}^{\mathrm{o}}$ existed in the activated and modified iron powders at the binding energy peak of $718 \mathrm{eV} \cdot{ }^{13}$ Simultaneously, a certain amount of the iron oxides were also displayed by the binding energy peaks of Fe $2 \mathrm{p}_{3 / 2}(711.0 \mathrm{eV})$ and $\mathrm{Fe} 2 \mathrm{p}_{1 / 2}(725.19 \mathrm{eV})$. The Fe $2 p_{3 / 2}$ and the Fe $2 p_{1 / 2}$ energy peaks still were observed at the surface of the raw iron powder, mainly due to oxidization by air. ${ }^{9,13}$ After the activation and modification treatment, the surface of the zero-valent iron powders, such as hematite, goethite and magnetite, was oxidized to the $\mathrm{Fe}(\mathrm{III})$ oxidation state, according to the results of the SEM, XRD and the XPS Fe $2 \mathrm{p}$ analyses.

The $\mathrm{Sb} 3 \mathrm{~d}_{3 / 2}$ peaks were found at the $540.19 \mathrm{eV}$, which appeared in both the modified iron powders after the adsorption of $\mathrm{Sb}(\mathrm{III})$ and $\mathrm{Sb}(\mathrm{v}) .{ }^{13}$ According to results in Table 3 , the surface contents of $\mathrm{Sb}(\mathrm{III})$ and $\mathrm{Sb}(\mathrm{v})$ were $6.6 \%$ and $4.49 \%$, respectively. Because of the similar binding energies, the $\mathrm{Sb}$ (III) and $\mathrm{Sb}(\mathrm{v})$ oxidation states cannot be distinguished. Furthermore, the combination of $\mathrm{Sb}$ (III) and $\mathrm{Sb}(\mathrm{v})$ adsorbed on the surface of the iron oxides cannot be distinguished because of the lack of reported binding energy references in the literature to correlate this. Nevertheless, the $\mathrm{Sb} 3 \mathrm{~d}_{3 / 2}$ binding energy peaks demonstrated that $\mathrm{Sb}(\mathrm{III})$ and $\mathrm{Sb}(\mathrm{v})$ in the solution were both chemically adsorbed onto the surface of the modified iron powders. Moreover, the intensity of the $\mathrm{Sb} 3 \mathrm{~d}_{3 / 2}$ peak for the modified iron powder adsorbed $\mathrm{Sb}$ (III) was stronger than the powders which adsorbed $\mathrm{Sb}(\mathrm{v})$, which was in agreement with the higher binding affinity of $\mathrm{Sb}(\mathrm{III})$ to the iron oxides on the surface of the modified iron powders than $\mathrm{Sb}(\mathrm{v})$ and was consistent with the experimental results of the adsorption isotherm. ${ }^{9,13}$

3.6.2 FT-IR spectroscopy analyses. The FT-IR spectroscopy analyses of the raw iron powders and the modified iron powder adsorbed $\mathrm{Sb}$ (III) and $\mathrm{Sb}(\mathrm{v})$ are presented in Fig. 8. The broad spectroscopy peak located at about $3462.7 \mathrm{~cm}^{-1}$ could be attributed to the $\mathrm{O}-\mathrm{H}$ bonds stretching resulting from the free water; the bands at $1648.9 \mathrm{~cm}^{-1}$ and $1384 \mathrm{~cm}^{-1}$ may be ascribed to the $\mathrm{C}-\mathrm{H}$ bonds stretching in the residual acetic acid when the iron powders were modified and the $1004.3 \mathrm{~cm}^{-1}$ peak could be attributed to the $\mathrm{C}-\mathrm{O}$ in the residual acetic acid or $\mathrm{CO}_{3}{ }^{2-}$ species. ${ }^{20,21}$ The spectroscopy peak at $664.4 \mathrm{~cm}^{-1}$ was likely to result from the $\mathrm{Fe}-\mathrm{O}-\mathrm{H}$ bands and the peaks at $465.7 \mathrm{~cm}^{-1}$ and $587.8 \mathrm{~cm}^{-1}$ could be attributed to the $\mathrm{Fe}-\mathrm{O}-\mathrm{Sb}$ bands, which demonstrated that the $\mathrm{Sb}(\mathrm{III})$ or $\mathrm{Sb}(\mathrm{v})$ in solution was adsorbed by the iron oxides on the surface of the modified iron powders. ${ }^{9,13}$

3.6.3 Schematic process diagram analyses. The images in Fig. 2 showed that the surface of the iron powders changed greatly after activation and modification and $\gamma-\mathrm{Fe}_{2} \mathrm{O}_{3}, \gamma-\mathrm{FeOOH}$ and $\mathrm{Fe}_{3} \mathrm{O}_{4}$ were obtained. Based on the images shown in Fig. 2, the schematic diagram for the adsorption process of the $\mathrm{Sb}$ (III) and $\mathrm{Sb}(\mathrm{v})$ by the modified iron powders is presented in Fig. 9. As described previously, the enhanced $\mathrm{Sb}(\mathrm{III})$ and $\mathrm{Sb}(\mathrm{v})$ removal rates were assigned to the mechanical activation and acid modification induced improvement in the physicochemical property of superficial corrosion. The mechanical activation and acid modification accelerated the loss of the electron from the iron atom and the oxygen corrosion of the surface. The probable reaction paths for iron corrosion and iron oxide formation are presented in Fig. 9. Under the action of $\mathrm{H}_{2} \mathrm{O}$ and $\mathrm{O}_{2}$, the surface $\mathrm{Fe}^{0}$ transformed into $\mathrm{Fe}^{2+}$ and $\mathrm{Fe}^{3+}$ was subsequently obtained. Then, part of $\mathrm{Fe}^{3+}$ was converted into $\mathrm{FeOOH}$ 
and amorphous $\mathrm{Fe}(\mathrm{OH})_{3}$; some $\mathrm{Fe}^{3+}$ changed into $\mathrm{Fe}_{3} \mathrm{O}_{4}$ with the use of $\mathrm{Fe}^{2+}$ and $\mathrm{O}_{2}$. The removal of $\mathrm{Sb}$ (III) and $\mathrm{Sb}(\mathrm{v})$ in the solution can not only be attributed to the adsorption by the iron, but also to the substitution of the hydrogen atom on the band of $\mathrm{O}-\mathrm{H}$ by $\mathrm{Sb}(\mathrm{III})$ and $\mathrm{Sb}(\mathrm{v})$ and the band $\mathrm{Fe}-\mathrm{O}-\mathrm{Sb}$ formed, which was determined in the XPS and FT-IR analyses.

\section{Conclusions}

In summary, an adsorbent was obtained using zero-valent iron powders by ball-milling and acid modification. Such iron oxides as $\mathrm{Fe}_{3} \mathrm{O}_{4}, \gamma-\mathrm{Fe}_{2} \mathrm{O}_{3}$ and $\gamma$ - $\mathrm{FeOOH}$ were obtained in the corrosion layer on the surface of the zero-valent iron powders. The modified iron powders were adopted to remove $\mathrm{Sb}(\mathrm{III})$ and $\mathrm{Sb}(\mathrm{v})$ in solution. The study showed that the experimental data fitted the Langmuir model and the pseudo-first-order kinetic model better and the adsorption process was monolayer and chemically controlled at pH $5.0 \pm 0.2$. The XPS and FT-IR analysis showed that the $\mathrm{O}-\mathrm{Sb}$ bond arose during the adsorption process. The schematic process diagram was completed to show the probable mechanism. The ball-milling and acid modification increased the adsorption capacity for $\mathrm{Sb}(\mathrm{III})$ and $\mathrm{Sb}(\mathrm{v})$ from $12.93 \mathrm{mg} \mathrm{g}^{-1}$ and $5.47 \mathrm{mg} \mathrm{g}^{-1}$ to $17.96 \mathrm{mg} \mathrm{g}^{-1}$ and $10.58 \mathrm{mg} \mathrm{g}^{-1}$, respectively. Although the adsorption capacities were relatively lower than those reported for pure iron oxides, the material availability contributed to the benefits of its application.

\section{Conflicts of interest}

There are no conflicts to declare.

\section{Acknowledgements}

This work was financially supported by the Natural Science Foundation of Hunan Province (2017JJ2020), the Outstanding Youth Project of the Department of Education of Hunan Province (16B049), the Science and Technology Projects of Yiyang (2015JZ26), the Science and Technology Program of Education Department of Hunan Province (16C0303) and the Science and Technology Program of Education Department of Hunan Province (18C0840).

\section{Notes and references}

1 C. Shan, Z. Ma and M. Tong, J. Hazard. Mater., 2014, 268, 229-236.
2 J. Xi, M. He, K. Wang and G. Zhang, J. Geochem. Explor., 2013, 132, 201-208.

3 J. Li, B. Zheng, Y. He, Y. Zhou, X. Chen, S. Ruan, Y. Yang, C. Dai and L. Tang, Ecotoxicol. Environ. Saf., 2018, 156, 125-134.

4 X. Li, X. Dou and J. Li, J. Environ. Sci., 2012, 24, 1197-1203. 5 J. Xi, M. He and C. Lin, Microchem. J., 2011, 97, 85-91.

6 V. J. Ritchie, A. G. Ilgen, S. H. Mueller, T. P. Trainor and R. J. Goldfarb, Chem. Geol., 2013, 335, 172-188.

7 X. Y. Guo, Y. T. Xin, H. Wang and Q. H. Tian, Trans. Nonferrous Met. Soc. China, 2015, 25, 4175-4182.

8 G. Ungureanu, S. Santos, B. Rui and C. Botelho, J. Environ. Manage., 2015, 151, 326-342.

9 Z. Qi, T. P. Joshi, R. Liu, H. Liu and J. Qu, J. Hazard. Mater., 2017, 329, 193-204.

10 R. Liu, W. Xu, Z. He, H. Lan, H. Liu, J. Qu and T. Prasai, Chemosphere, 2015, 138, 616-624.

11 K. Simeonidis, V. Papadopoulou, S. Tresintsi, E. Kokkinos, I. A. Katsoyiannis, A. I. Zouboulis and M. Mitrakas, Sustainability, 2017, 9, 238-249.

12 P. Fan, Y. Sun, J. Qiao, I. Lo and X. Guan, J. Hazard. Mater., 2017, 343, 266-275.

13 X. Zhao, X. Dou, M. Dinesh, P. U. Charles, S. O. Yong and J. Xin, Chem. Eng. J., 2014, 247, 250-257.

14 X. Guo, Z. Wu, M. He, X. Meng, X. Jin, N. Qiu and J. Zhang, J. Hazard. Mater., 2014, 276, 339-345.

15 F. Kolbe, H. Weiss, P. Morgenstern, R. Wennrich, W. Lorenz, K. Schurk, H. Stanjek and B. Daus, J. Colloid Interface Sci., 2011, 357, 460-465.

16 Z. Lan, J. Wei, Z. Xuan, F. Li and J. Feng, Chem. Eng. J., 2015, 277, 378-387.

17 X. Wang, M. He, C. Lin, Y. Gao and Z. Lei, Geochemistry, 2012, 72, 41-47.

18 B. J. Lafferty, M. Gindervogel, M. Zhu, K. J. T. Livi and D. L. Sparks, Environ. Sci. Technol., 2010, 44, 8467-8472.

19 K. Simeonidis, K. Kalaitzidou, E. Kaprara, G. Mitraka, T. Asimakidou, L. Balcells and M. Mitrakas, Water, 2019, 11. 20 Z. Qi, T. P. Joshi, R. Liu, Y. Li, H. Liu and J. Qu, J. Hazard. Mater., 2017, 343, 36.

21 L. R. Braga, A. A. Rosa and A. C. B. Dias, Anal. Methods, 2014, 6, 4029. 